\title{
Treatment of high fluoride-content wastewater by continuous electrocoagulation-flotation system with bipolar aluminum electrodes
}

\author{
Ching-Yao Hu ${ }^{\mathrm{a}}$, Shang-Lien Lo ${ }^{\mathrm{a}, *}$, Wen-Hui Kuan ${ }^{\mathrm{b}}$, Yu-De Lee ${ }^{\mathrm{a}}$ \\ ${ }^{a}$ Research Center for Environmental Pollution Prevention and Control Technology, Graduate Institute of Environmental Engineering, \\ National Taiwan University, No. 71 Chou-shan Road, Taipei 106, Taiwan, ROC \\ ${ }^{\mathrm{b}}$ Department of Environmental and Safety Engineering, Ming-Chi University of Technology, Taishan, Taipei County 243, Taiwan, ROC
}

Received 14 November 2006; received in revised form 9 July 2007; accepted 11 July 2007

\begin{abstract}
A continuous electrocoagulation-flotation (ECF) system was employed to treat synthetic high fluoride-content wastewater following calcium precipitation. The dose of sodium dodecyl sulfate (SDS) in a continuous ECF system was higher than that in the batch system indicating the SDS acted not only as frother, but also as collector in the continuous system. The removal of suspended solids (SS) in the continuous system was less than that in the batch system because the scum was disturbed by the flow of wastewater in the flotation tank. It decreased with the increase in flow rate when the flow rate reaches higher than $800 \mathrm{~mL} / \mathrm{min}$, yet it increased with the increase in flow rate when the flow rate falls under $200 \mathrm{~mL} / \mathrm{min}$. Two parameters, gas/liquid ratio $\left(\Gamma_{\mathrm{G} / \mathrm{L}}\right)$ and gas/solid ratio $\left(\Gamma_{\mathrm{G} / \mathrm{S}}\right)$, were determined to indicate the discontinuity of the flow and flotation ability, respectively, in order to explain the phenomenon. The result indicates that the flotation ability was insufficient when $\Gamma_{\mathrm{G} / \mathrm{s}}$ was under $0.1 \mathrm{~L} / \mathrm{g}$ and the flow of wastewater became discontinuous when $\Gamma_{\mathrm{G} / \mathrm{L}}$ was over 0.4. Both of these situations would lead to the increase of SS.
\end{abstract}

(C) 2007 Elsevier B.V. All rights reserved.

Keywords: Fluoride; Electrocoagulation-flotation (ECF); Calcium precipitation; Sodium dodecyl sulfate (SDS)

\section{Introduction}

Fluoride concentration in drinking water ranging from 0.5 to $0.8 \mathrm{mg} / \mathrm{L}$ prevents people from getting dental cavities, but long-term intake of water that contains more than $1.5 \mathrm{mg} / \mathrm{L}$ of fluoride may cause bone disease and mottling of the teeth [1-4]. Treating high fluoride-content wastewater efficiently has been an important issue for environmental engineers because of the dramatic development of the semiconductor industry which uses a large amount of hydrofluoric acid in etching and quartz cleaning operations $[5,6]$. Several methods such as alum coagulation [7-11], adsorption [12-16], reverse osmosis (RO) [17], electrodialysis [18], calcite filters [19,20], selective ion exchange [21], and electrochemical methods [22-25] have been employed or tested for defluoridation. The method of fluoride removal from high fluoride-content industrial wastewater generally involves a chemical precipitation process [5-10]. This process produces

\footnotetext{
* Corresponding author. Tel.: +886 223625373; fax: +886223928821.

E-mail address: sllo@ntu.edu.tw (S.-L. Lo).
}

calcium fluoride $\left(\mathrm{CaF}_{2}\right)$ particles through the addition of lime or another calcium salt, such as $\mathrm{CaCl}_{2}$ (Eq. (1)):

$\mathrm{Ca}_{(\mathrm{aq})}{ }^{2+}+2 \mathrm{~F}_{(\mathrm{aq})}{ }^{-} \rightarrow \mathrm{CaF}_{2(\mathrm{~s})}$

Moreover $\mathrm{CaF}_{2}$ particles are too tiny to be removed without coagulation. Therefore, alternative process is needed to lower the suspended solids (SS) and fluoride concentration after calcium precipitation.

The wastewater after calcium precipitation with addition of a stoichiometric amount of calcium salt contains both SS and soluble fluoride ions. Our previous study [26] has shown that the electrocoagulation-flotation (ECF) process with the addition of an anodic surfactant, sodium dodecyl sulfate (SDS), can effectively remove the SS and soluble fluoride ions simultaneously in a batch experiment [26]. In ECF cells, Al(III) and hydrogen gas are produced stoichiometrically when electric current passes through the aluminum electrodes (Eqs. (2) and (3)):

$$
\begin{aligned}
& \mathrm{Al}_{(\mathrm{s})} \rightarrow \mathrm{Al}_{(\mathrm{aq})}{ }^{3+}+3 \mathrm{e}^{-} \\
& 2 \mathrm{H}_{2} \mathrm{O}_{(\mathrm{l})}+2 \mathrm{e}^{-} \rightarrow 2 \mathrm{OH}_{(\mathrm{aq})}{ }^{-}+\mathrm{H}_{2(\mathrm{~g})}
\end{aligned}
$$


The $\mathrm{CaF}_{2}$ particles can be removed by coagulation of $\mathrm{Al}(\mathrm{III})$ ions, flotation of hydrogen gas, or a combination of these, and the fluoride ions can be removed by coprecipitation of $\mathrm{Al}(\mathrm{III})$ ions.

Most plants use continuous systems to treat wastewater to save on operation costs [27-29]. The physical and chemical phenomena may be different between continuous and batch ECF systems [29]. A continuous electrocoagulation-flotation (ECF) system, therefore, was established to evaluate the feasibility of implementing an ECF system to treat high fluoride-content wastewater in this study.

\section{Materials and methods}

Synthetic wastewater was prepared by mixing stoichiometric amounts of sodium fluoride $(10 \mathrm{~g} \mathrm{~F})$ and calcium chloride $(42.6 \mathrm{~g}$ $\left.\mathrm{CaCl}_{2} \cdot 2 \mathrm{H}_{2} \mathrm{O}\right)$ with D.I. water $(20 \mathrm{~L})$ to simulate the semiconductor wastewater after calcium precipitation. The initial $\mathrm{pH}$, fluoride concentration and SS in the synthetic solution were 5.6, $27.8 \mathrm{mg} / \mathrm{L}$ and $832 \mathrm{mg} / \mathrm{L}$, respectively. Various amounts of SDS stock solution were added to the synthetic solution to investigate the influence of SDS concentration on the performance of the ECF process. All chemicals used in this study were reagent grade.

Fig. 1 demonstrates the layout of the continuous ECF system. Mechanical stirring at $100 \mathrm{rpm}$ maintained a homogeneous solution and prevented the sedimentation of $\mathrm{CaF}_{2}$ particles in the storage tank. The synthetic high fluoride-content wastewater after calcium precipitation was fed to the ECF reactor with a pump. The electrolysis cell comprised nine aluminum electrodes (100 $\mathrm{mm} \times 40 \mathrm{~mm}, 99 \%$ purity). Only the outer electrodes were connected to the power source. The distance between each electrode was $10 \mathrm{~mm}$. The volume $(V)$ of the reactor is $320 \mathrm{~mL}$. A constant current was maintained using a potentiostat in intensiostat mode. This work used aluminum as the sacrificial anode, rather than iron, because the residual ferrous ions are easily oxidized by air, which may color the effluent water. Scum was separated out using a flotation apparatus, and flotation was achieved by hydrogen gas bubbles generated from the cathode, allowing the top layer to be skimmed and clean water regularly tapped.

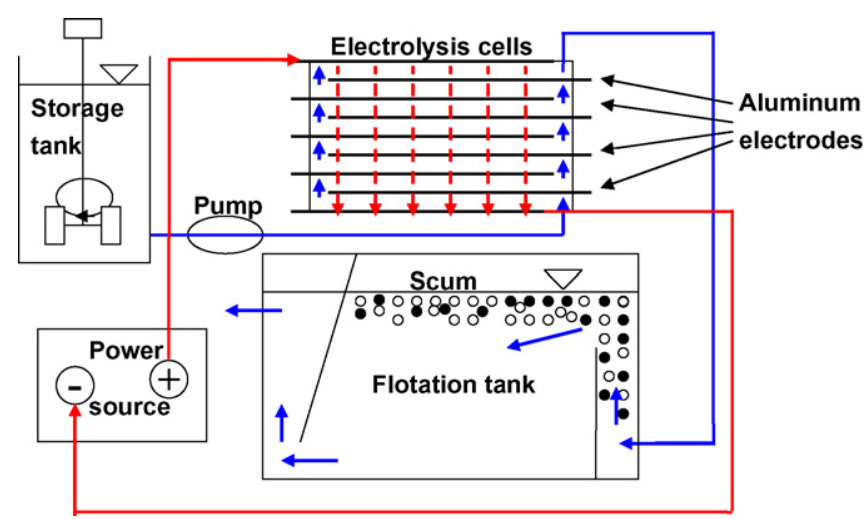

Fig. 1. Schematic diagram of the continuous ECF system; the blue and red lines represent the wastewater and electric flows, respectively. (For interpretation of the references to colour in this figure legend, the reader is referred to the web version of the article.)
A $100 \mathrm{~mL}$ volume of treated solution was sampled after five times the hydraulic retention time of the flotation tank. SS was measured by a modified method described by Huang and Liu [5]. A $0.2 \mu \mathrm{m}$ membrane filter was used to prevent the fine $\mathrm{CaF}_{2}$ particles from flowing through. The concentration of fluoride was measured using a specific fluoride electrode (Orion Research Inc., ion plus fluoride 9609BN, USA). A TISAB II buffer solution containing CDTA (trans-1,2-diaminocyclo-hexane- $N, N, N^{\prime}$, $N^{\prime}$-tetra-acetic acid, Orion Research Inc.) was added to the sample to prevent interference from other ions $\left(\mathrm{Al}^{3+}, \mathrm{Fe}^{3+}\right.$, etc.) during the measurement of the fluoride concentration [12].

\section{Results and discussions}

\subsection{Effect of the concentration of SDS}

Fig. 2 shows the variations of SS removal and residual $\left[\mathrm{F}^{-}\right]$ with the concentration of SDS. The finial $\mathrm{pH}$ in all systems is around 9.0. The SS removal rose with the increase in the concentration of SDS. In the batch system, only $5 \mathrm{mg} / \mathrm{L}$ of SDS is needed to achieve over $95 \%$ of SS removal [26]. In the continuous system, however, over $30 \mathrm{mg} / \mathrm{L}$ of SDS is needed. This fact may be the consequent effect of a much shorter retention time in the continuous system. In the batch experiment, the retention time was over $9 \mathrm{~min}$. Therefore, there was enough time for aluminum hydroxide flocs to grow and act as a collector to catch most of the $\mathrm{CaF}_{2}$ particles. In the continuous system, however, the hydraulic retention time in ECF reactor was only about $1 \mathrm{~min}$. There was not enough time for aluminum hydroxide flocs to grow and catch all the $\mathrm{CaF}_{2}$ particles. The SDS concentration, therefore, needed to be increased to act not only as frother but also as collector. The SDS concentration needed for the continuous ECF system, thus, is higher than that for the batch system, but is still lower than that $(50 \mathrm{mg} / \mathrm{L})$ of a dispersed air flotation system [5], because some $\mathrm{CaF}_{2}$ particles can still be caught by aluminum hydroxide flocs.

It is notable that the residual fluoride concentration also rose with the increase of the concentration of SDS. This phenomenon should be due to the inhibitory effect of anodic surfactant on the crystallization process of $\mathrm{CaF}_{2}$. Researchers stated that the electrostatic adsorption of anodic surfactant on lateral crystal

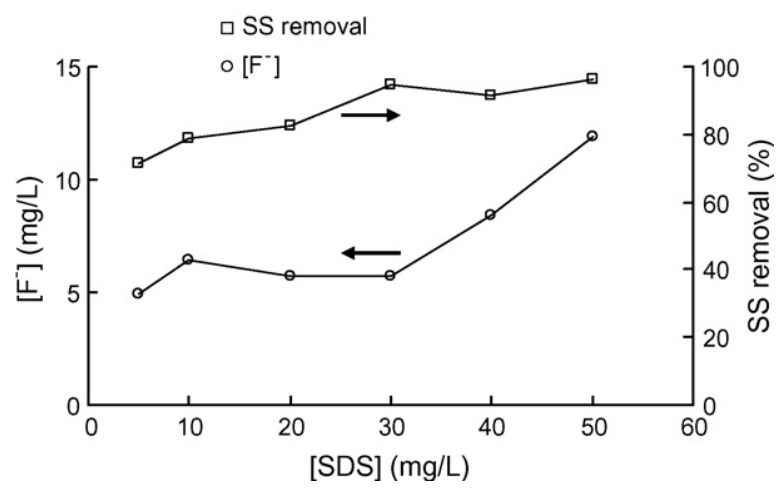

Fig. 2. Variations of SS removal and residual $\left[\mathrm{F}^{-}\right]$with the concentration of SDS (initial SS $=832 \mathrm{mg} / \mathrm{L},\left[\mathrm{F}^{-}\right]_{0}=27.4 \mathrm{mg} / \mathrm{L}, Q_{\mathrm{L}}=300 \mathrm{~mL} / \mathrm{min}, I=1.0 \mathrm{~A}$, final $\mathrm{pH}$ 9.0). 


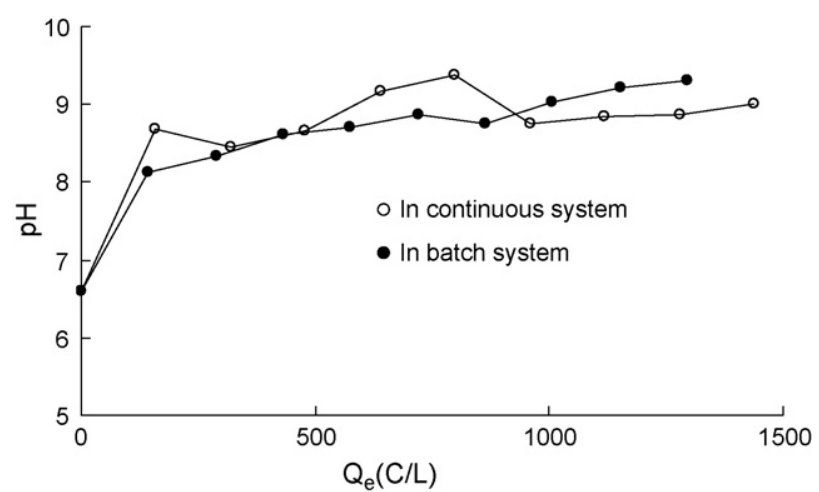

Fig. 3. Vartiations of finial $\mathrm{pH}$ with $Q_{\mathrm{e}}$ in batch and continuous systems (initial $\left.\mathrm{SS}=832 \mathrm{mg} / \mathrm{L},\left[\mathrm{F}^{-}\right]_{0}=27.4 \mathrm{mg} / \mathrm{L}, Q_{\mathrm{L}}=300 \mathrm{~mL} / \mathrm{min},[\mathrm{SDS}]=30 \mathrm{mg} / \mathrm{L}\right)$.

faces inhibited crystal growth of calcium hydrogen phosphate dehydrate precipitate and changed crystal morphology [30]. The kinetics of the precipitation of calcium carbonate is also inferred by SDS which is an anodic surfactant [31]. The crystallization of $\mathrm{CaF}_{2}$ may also be influenced by SDS.

\subsection{The effect of charge loading}

Charge loading $\left(Q_{\mathrm{e}}\right)$ was defined as Eq. (4) in the batch experiment to examine the influence of current on SS removal and residual $\left[\mathrm{F}^{-}\right]$:

$Q_{\mathrm{e}}=\frac{n I t}{V}$

where $n$ is the cells number, $I$ is the current (A), $t$ is the reaction time and $V$ is the volume of reactor. Both aluminum dosage released from anodes (which can remove fluoride ions) and the amounts of hydrogen gas generated from the cathode (which can remove SS) are proportional to $Q_{\mathrm{e}}[25,26]$. In the continuous system, the equation can be rewritten as follows:

$Q_{\mathrm{e}}=\frac{n I}{Q_{\mathrm{L}}}$

where $Q_{\mathrm{L}}$ is the flow rate.

Figs. 3-5 compare the vartiations of the finial $\mathrm{pH}, \mathrm{SS}$ removal and residual $\left[\mathrm{F}^{-}\right]$with $Q_{\mathrm{e}}$ in the batch and continuous systems. Similar tendencies were observed in the two systems. The finial

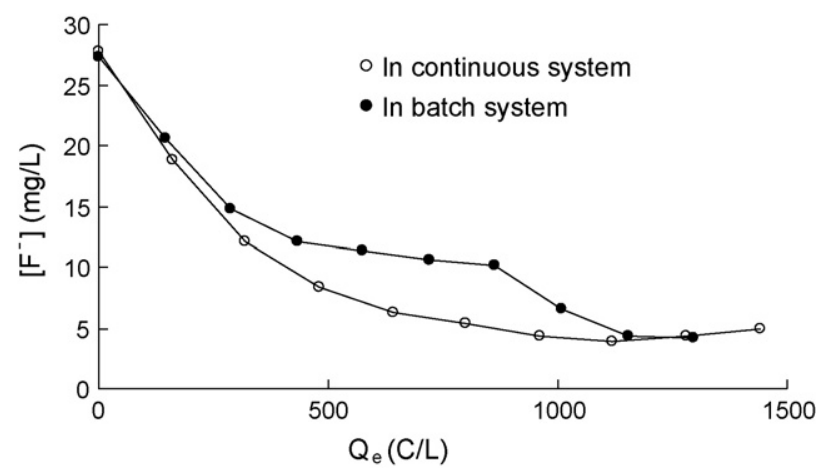

Fig. 4. Vartiations of residual $\left[\mathrm{F}^{-}\right]$with $Q_{\mathrm{e}}$ in batch and continuous systems (initial SS $=832 \mathrm{mg} / \mathrm{L},\left[\mathrm{F}^{-}\right]_{0}=27.4 \mathrm{mg} / \mathrm{L}, Q_{\mathrm{L}}=300 \mathrm{~mL} / \mathrm{min},[\mathrm{SDS}]=30 \mathrm{mg} / \mathrm{L}$ ).

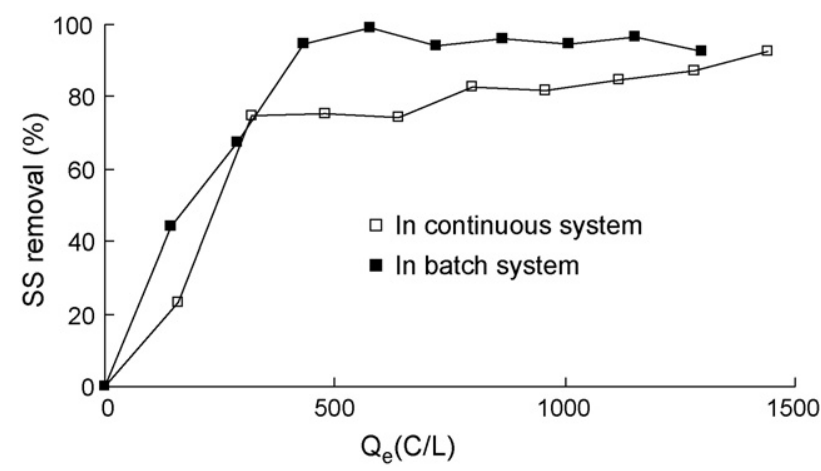

Fig. 5. Vartiations of SS removal with $Q_{\mathrm{e}}$ in batch and continuous systems (initial $\left.\mathrm{SS}=832 \mathrm{mg} / \mathrm{L},\left[\mathrm{F}^{-}\right]_{0}=27.4 \mathrm{mg} / \mathrm{L}, Q_{\mathrm{L}}=300 \mathrm{~mL} / \mathrm{min},[\mathrm{SDS}]=30 \mathrm{mg} / \mathrm{L}\right)$.

$\mathrm{pH}$ rose slightly from 8.0 to 9.0 with the increase of $Q_{\mathrm{e}}$ in both systems because the defluoridation leads to the liberation of $\mathrm{OH}^{-}$ions [22-26] (Eq. (6)):

$$
\mathrm{Al}_{n}(\mathrm{OH})_{3 n(\mathrm{~s})}+m \mathrm{~F}_{(\mathrm{aq})}{ }^{-} \rightarrow \mathrm{Al}_{n} \mathrm{~F}_{m}(\mathrm{OH})_{3 n-m(\mathrm{~s})}+m \mathrm{OH}_{(\mathrm{aq})}{ }^{-}
$$

The dissolved aluminum concentrations in all systems were around $10 \mathrm{mg} / \mathrm{L}$. This should be due to the dissolution of aluminum hydroxide in alkaline solution as following reaction:

$$
\mathrm{Al}(\mathrm{OH})_{3(\mathrm{~s})}+\mathrm{OH}_{(\mathrm{aq})}{ }^{-} \rightarrow \mathrm{Al}(\mathrm{OH})_{4(\mathrm{aq})}{ }^{-}
$$

The SS removal remained at 95 and $80 \%$ in the batch and continuous systems, respectively, and the residual $\left[\mathrm{F}^{-}\right]$were under $10 \mathrm{mg} / \mathrm{L}$ in both systems when $Q_{\mathrm{e}}$ exceeded $500 \mathrm{C} / \mathrm{L}$. It is notable that the SS removal in the batch system was higher than that in the continuous system. This fact should be due to the scum being disturbed by the flow current and skimming in the flotation tank. The $\mathrm{CaF}_{2}$ particles may have been released from the scum as it was disturbed.

\subsection{The effect of flow rate}

Fig. 6 shows the variations of SS removal and residual $\left[\mathrm{F}^{-}\right]$ with $Q_{\mathrm{L}}$. The removal of both SS and fluoride ions were acceptable within the range of $Q_{\mathrm{L}}$ from 200 to $800 \mathrm{~mL} / \mathrm{min}$. It is rational

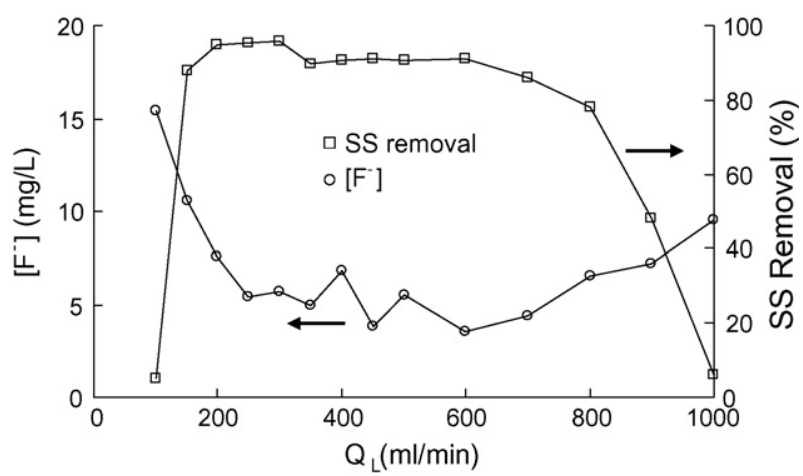

Fig. 6. Variations of $\mathrm{SS}$ removal and residual $\left[\mathrm{F}^{-}\right]$with $Q_{\mathrm{L}}$ (initial $\mathrm{SS}=832 \mathrm{mg} / \mathrm{L},\left[\mathrm{F}^{-}\right]_{0}=27.4 \mathrm{mg} / \mathrm{L}, I=1.0 \mathrm{~A},[\mathrm{SDS}]=30 \mathrm{mg} / \mathrm{L}$, finial $\mathrm{pH}$ values were ranged from 8.5 to 9.0 ). 
that the removal of SS and fluoride ions decreased with the increase of $Q_{\mathrm{L}}$, because the increase of $Q_{\mathrm{L}}$ decreases $Q_{\mathrm{e}}$ as shown in Eq. (5). However, it is unexplainable why the removal of SS dropped with the decrease of $\mathrm{Q}_{\mathrm{L}}$.

It was observed that the flow became unsteady and big bubbles spouted casually from the inlet to the flotation tank when $Q_{\mathrm{L}}$ was lower than $200 \mathrm{~mL} / \mathrm{min}$. The spurting flow agitated the scum and released the $\mathrm{CaF}_{2}$ particles. It seems too much hydrogen gas was produced during the ECF reaction which broke the continuity of the flow. This could be the reason as to why the removal of SS and fluoride ions dropped with the decrease of $Q_{\mathrm{L}}$. The electrolysis cell is a closed system. The hydrogen gas could not escape from the cell and had to mix with the water flow. It is reasonable that some of the hydrogen bubbles could not mix with the water if the gas was too much. Big bubbles, therefore, appeared and the water flow became unsteady.

It seems that the drop of SS removal was due to too little or too much hydrogen being produced. Combining Faraday's Law (Eq. (8)) and the ideal gas law (Eq. (9)), the hydrogen gas produced during ECF $\left(V_{\mathrm{H}_{2}}\right)$ can be calculated by Eq. (10):

$N=\frac{Q_{\mathrm{e}} \theta_{\mathrm{H}}}{Z F}$

$V_{\mathrm{H}_{2}}=\frac{N R T}{P}$

and

$V_{\mathrm{H}_{2}}=\frac{R T Q_{\mathrm{e}} \theta_{\mathrm{H}}}{Z F P}$

where $N$ is the mole of hydrogen gas produced during ECF, $\theta_{\mathrm{H}}$ is the hydraulic retention time in ECF cell, $R$ is the ideal gas constant, $T$ is the Kelvin temperature, $Z$ is the valence $(Z=2$ for hydrogen gas) and $P$ is the pressure. To prove above inference, two parameters, gas/liquid ratio $\left(\Gamma_{\mathrm{G} / \mathrm{L}}\right)$ and gas/solid ratio $\left(\Gamma_{\mathrm{G} / \mathrm{S}}\right)$, were determined as follows:

$\Gamma_{\mathrm{G} / \mathrm{L}}=\frac{V_{\mathrm{H}_{2}}}{V}=\frac{n I R T}{Z F P Q_{\mathrm{L}}}$

and

$\Gamma_{\mathrm{G} / \mathrm{S}}=\frac{V_{\mathrm{H}_{2}}}{V[\mathrm{SS}]_{0}}=\frac{n I R T}{Z F P Q_{\mathrm{L}}[\mathrm{SS}]_{0}}$

where $[\mathrm{SS}]_{0}$ is the initial SS, $\Gamma_{\mathrm{G} / \mathrm{L}}$ the volume ratio of the hydrogen gas produced to the solution indicating the discontinuity of the flow, and $\Gamma_{\mathrm{G} / \mathrm{S}}$ is the volume of hydrogen gas per unit weight of SS indicating the flotation ability. Fig. 7 shows the variation of SS removal with $\Gamma_{\mathrm{G} / \mathrm{L}}$ and $\Gamma_{\mathrm{G} / \mathrm{S}}$. The SS removal rose when $\Gamma_{\mathrm{G} / \mathrm{S}}$ was under $0.1 \mathrm{~L} / \mathrm{g}$ and $\Gamma_{\mathrm{G} / \mathrm{L}}$ was over 0.4 . This result reveals that the flotation ability was not enough to float the flocs as $\Gamma_{\mathrm{G} / \mathrm{S}}$ was under $0.1 \mathrm{~L} / \mathrm{g}$, and the continuity of the flow was broken as $\Gamma_{\mathrm{G} / \mathrm{L}}$ was over 0.4 . The lower limit of $\Gamma_{\mathrm{G} / \mathrm{S}}$ may vary with the change of the nature of particles and types of frother or collector. So, it may not be applicable in other systems used to remove other pollutants. However, the upper limit of $\Gamma_{\mathrm{G} / \mathrm{L}}$ should be independent from the nature of pollutants. It should be applicable in other ECF systems as long as the ECF reactor is a closed system.

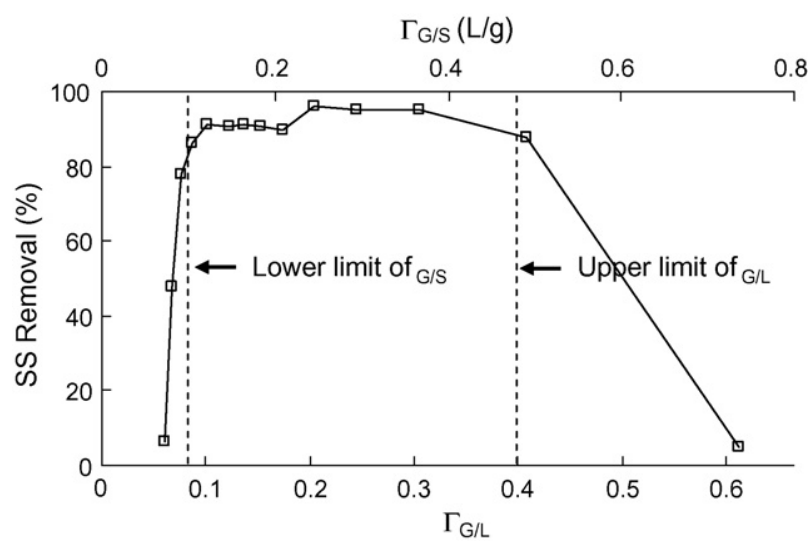

Fig. 7. Variation of SS removal with $\Gamma_{\mathrm{G} / \mathrm{L}}$ and $\Gamma_{\mathrm{G} / \mathrm{S}}$ (initial SS $=832 \mathrm{mg} / \mathrm{L}$, $\left[\mathrm{F}^{-}\right]_{0}=27.4 \mathrm{mg} / \mathrm{L}, I=1.0 \mathrm{~A},[\mathrm{SDS}]=30 \mathrm{mg} / \mathrm{L}$, finial $\mathrm{pH}$ values were ranged from 8.5 to 9.0 ).

\section{Conclusion}

A continuous bipolar electrocoagulation-flotation system was developed for the treatment of high fluoride-content wastewater following calcium precipitation with SDS. Wastewater could be effectively treated by the system, but a higher dose of SDS than batch system was needed. The tendency of SS removal and residual $\left[\mathrm{F}^{-}\right]$with $Q_{\mathrm{e}}$ in the batch and continuous ECF systems were similar, but SS removal in the continuous system was less than that in the batch system. SS removal dropped when too much or too little hydrogen gas was produced during ECF. The continuity of flow broke when $\Gamma_{\mathrm{G} / \mathrm{L}}$ was over 0.4 , and the flotation ability was not enough to float all of the SS when $\Gamma_{\mathrm{G} / \mathrm{S}}$ was under $0.1 \mathrm{~L} / \mathrm{g}$ in the continuous ECF system.

\section{Acknowledgement}

The authors would like to thank the National Science Council of Chinese Taiwan for financially supporting this research under Contract No. NSC 94-2211-E-002-002.

\section{References}

[1] W.E. Brown, J.M. Gregry, L.C. Chow, Effects of fluoride on emanal solubility and cariostasis, Caries Res. 11 (1977) 118-141.

[2] C.F. Lynch, Relationship of fluorine in drinking waters to other drinking waters parameters, Arch. Environ. Health 42 (1987) 5-13.

[3] J.A. Nell, G. Livanos, Effects of fluoride concentration in seawater on growth and fluoride accumulation by Sydney rock oyster (Saccostrea commercialis) and flat oyster (Ostrea angasi) spat, Water Res. 22 (1988) 749-753.

[4] A.R. Mansson, G.M. Withford, Environmental and physiological factors affecting dental fluorides, J. Dent. Res. 69 (1990) 706-713.

[5] C.J. Huang, J.C. Liu, Precipitation flotation of fluoride-containing wastewater from semi-conductor manufacture, Water Res. 33 (1999) 3403-3412.

[6] T.C. Chuang, C.J. Huang, J.C. Liu, Treatment of semiconductor wastewater by dissolved air flotation, J. Environ. Eng. 128 (2002) 974-980.

[7] J. Buffle, N. Parthasarathy, W. Haerdi, Importance of speciation methods in analytical control of water treatment processes with application to fluoride removal from wastewater, Water Res. 19 (1985) 7-23.

[8] N. Parthasarathy, J. Buffle, W. Haerdi, Combined use of calcium salts and polymeric aluminium hydroxide for defluoridation of waste waters, Water Res. 20 (1986) 443-448. 
[9] S. Saha, Treatment of aqueous effluent for fluoride removal, Water Res. 8 (1993) 7-1350.

[10] D.F. Lawler, D.H. Williams, Equalization/neutralization modeling: an application to fluoride removal, Water Res. 18 (1984) 1411-1419.

[11] M.G. Sujana, R.S. Thakur, S.B. Rao, Removal of fluoride from aqueous solution by using alum sludge, J. Colloid Interf. Sci. 206 (1998) 94-101.

[12] O.J. Hao, C.P. Huang, Adsorption characteristics of fluoride onto hydrous alumina, J. Environ. Eng. 112 (1986) 1054-1069.

[13] T.M. Suzuki, C. Chida, M. Kanesato, T. Yokoyama, Removal of fluoride ion by a porous spherical resin loaded with hydrous zirconium oxide, Chem. Lett. 7 (1989) 1155-1158.

[14] N. Azbar, A. Turkman, Defluorination in drinking waters, Water Sci. Technol. 42 (2000) 403-407.

[15] A.K. Chaturvedi, K.P. Yadava, K.C. Pathak, V.N. Singh, Defluorination of water by adsorption on fly ash, Water Air Soil Pollut. 49 (1990) 41-69.

[16] Q. Zhang, H. Liang, Aluminium phosphate for the defluorination of potable water, Environ. Int. 18 (1992) 307-310.

[17] P.I. Ndiaye, P. Moulln, L. Dominguez, J.C. Millet, F. Charbit, Removal of fluoride from electronic industrial effluent by RO membrane separation, Desalination 173 (2005) 25-32.

[18] M. Hichour, F. Persin, J. Sandeaux, Fluoride removal from waters by Donnan dialysis, Sep. Purif. Technol. 18 (2000) 1-11.

[19] Y. Min, H. Takayuki, H. Nobuyuki, M. Haruki, Fluoride removal in a fixed bed packed with granular calcite, Water Res. 33 (1999) 3395-3422.

[20] E.J. Reardon, Y. Wang, Limestone reactor for fluoride removal from wastewaters, Environ. Sci. Technol. 34 (2000) 3247-3253.

[21] K.M. Popat, P.S. Anand, B.D. Dasare, Selective removal of fluoride ion from water by the aluminium from of the aminomethylphosphonic acidtype ion exchanger, React. Polym. 23 (1994) 23-32.
[22] M. Lui, R.Y. Sun, J.H. Zhang, Y. Bina, L. Wei, P. Lui, F. Keichero, Elimination of excess fluoride in potable water with coarcervation by electrolysis using aluminum anode, Fluoride 20 (1983) 54-63.

[23] N. Mameri, A.R. Yeddou, H. Lounici, D. Belhocine, H. Grib, B. Bariou, Defluoridation of septentrional Sahara water of North Africa by electrocoagulation process using bipolar aluminium electrode, Water Res. 32 (1998) 604-612.

[24] C.Y. Hu, S.L. Lo, W.H. Kuan, Effects of co-existing anions on fluoride removal in electrocoagulation (EC) process using aluminum electrodes, Water Res. 37 (2003) 4513-4523.

[25] F. Shen, X. Chen, P. Gao, G. Chen, Electrochemical removal of fluoride ions from industrial wastewater, Chem. Eng. Sci. 58 (2003) 987-993.

[26] C.Y. Hu, S.L. Lo, W.H. Kuan, Y.D. Lee, Removal of fluoride from semiconductor wastewater by electrocoagulation-flotation (ECF), Water Res. 39 (2005) 895-901.

[27] G. Chen, Electrocoagulation technologies in wastewater treatment, Sep. Purif. Technol. 38 (2004) 11-41.

[28] J. Ge, J. Qu, P. Lei, H. Liu, New bipolar electrocoagulation-electroflotation process for the treatment of laundry wastewater, Sep. Purif. Technol. 36 (2004) 33-39.

[29] C.J. Lin, S.L. Lo, C.Y. Kuo, C.H. Wu, Pilot-scale electrocoagulation with bipolar aluminum electrodes for on-site domestic grey water reuse, J. Environ. Eng. 131 (2005) 491-495.

[30] M. Bujan, M. Sikiric, N. Filipovic-Vincekovic, N. Vdovic, N. Garti, H. Furedi-Milhofer, Effect of anionic surfactants on crystal growth of calcium hydrogen phosphate dehydrate, Langmuir 17 (2001) 6461-6470.

[31] E. Chibowski, A. Szczes, L. Holysz, Influence of sodium dodecyl sulfate and static magnetic field on the properties of freshly precipitated calcium carbonate, Langmuir 21 (2005) 8114-8122. 